\title{
The Development of Tuvan Literature During the Soviet Period (1960-80-s)
}

\author{
Liudmila S. Mizhit* \\ Tuvan Institute of Humanitarian \\ and Applied Socio-economic Research \\ 4 Kochetov Str., Kyzyl, 667000, Republic of Tuva
}

Received 11.11.2016, received in revised form 06.04.2018, accepted 10.04.2018

This article examines the history of Tuvan literature in the Soviet era, namely the 1960-80-s of the 20th century, when it was intensively developing within the creative dialogue of literatures and cultures of different peoples of the Soviet Union. This is the most fruitful and busy period of Tuvan literature, not only in terms of enrichment of the genre system, but also in terms of creating a large, brandmark works of the national literature: novels, plays and poetry. The founders of Tuvan literature are: Saltchak Toka, Stepan Saryg-ool, Sergei Piurbiu, Viktor Kok-ool, the next generation is represented by KyzylEnik Kudazhy, Mongush Kenin-Lopsan, Salim Siuriun-ool, Vasilii Mongush, Iurii Kiunzhgesh and others. Despite the influence of Communist ideology and principles of socialist realism, some Tuvan poets (Mongush Dorgu, Alexandr Darzhai, Igor Irgit, Anton Uerzhaa, Nikolai Kuular) were able to get away from the socio-political view of reality and avoid the stereotypes.

The article summarizes one of the brightest stages of development of Tuvan literature. It has practical significance in the study of Soviet literature in the contemporary scientific paradigms.

Keywords: Tuvan literature, history of Soviet literature, socialist realism, ideology, pathos, prose, poetry, drama, children's literature, innovation, the literary process.

DOI: 10.17516/1997-1370-0249.

Research area: Literature of peoples of the Russian Federation (Tuvan literature).

Since the beginning of the new century, the present generation of Tuvan literary critics has been working on a more complete, deep and objective understanding of the historical and literary past of its people, because, as the wellknown literary theorist R.F. Iusufov wrote, "An important task of modern literature studies is a critical assessment of the $20^{\text {th }}$ century's heritage and development of the non-ideological history of literature on its basis" (Iusufov, 1996). Currently,
Tuvan Institute of Humanities and Applied Social and Economic Research is running a project for a new understanding of the literary heritage of Tuva. The first volume of this collective work titled "The History of Tuvan literature. The Origins. Literature of the People's Republic of Tuva (19211944)" was published in 2013 (Bicheldei, Mizhit, 2013). The work presents of a research of Tuvan literature history of the socialist (before 1991) and the post-Soviet era.

(c) Siberian Federal University. All rights reserved

* Corresponding author E-mail address: 1mizhit@mail.ru 
In the history of the original national Tuvan literature, which began in the 30 -s of the $20^{\text {th }}$ century, there is an intensive development period of the 1960-80-s, which coincided with significant cultural achievements and establishment of aesthetic values of the Soviet society, characterized with the general rise of ideological, political, social, economic and cultural life in Tuva and the entire Soviet Union. It was closely associated with the scientific and technological progress, the development of education and science, art and literature, expansion of international creative relationships in the sphere of culture etc.

The development of Tuvan Soviet literature in the framework of socialist realism, reported in the studies of the 1960-s, intensified literary criticism and created an integral picture of the formation and development of Tuvan literature, its relation to folklore and poetic heritage. In 1964, "Tuvan Literature" essay (in Tuvan language), written by A.K. Kalzan, D.S. Kuular, M.B. Kenin-Lopsan, Iu.Sh. Kiunzhgesh, et al., was published (Kalzan et al., 1964); in 1975, "Essays on the History of Tuvan Soviet literature" (in Tuvan language) by A.K. Kalzan, D.S. Kuular, M.A. Khadakhane (Kalzan et al., 1975), saw the light. In those and subsequent years, more research on the history of Tuvan literature has been conducted (Kuular, 1970; Samdan, 1987).

As Gamzatov G.G. fairly noticed, “...literary concepts and attitudes of that time need to be reviewed and rethought. <...> Over the past decade, Russian literary criticism has gained a wealth of experience and has done a fundamental leap in the methodology of its studies, which helps us in writing a truly scientific, thorough, updated history of the regional literary system in general and its ethnic components" (Gamzatov, 2003).

In the $20^{\text {th }}$ century Tuvan literature, as well as all national literatures of the USSR, was developed on the principles of the main artistic trend of the epoch, socialist realism, which "affirmed the artistic concept: a socially active personality involved in the violent process of history-making" (Borev, 2001: 403). Literature and art in general were dominated by the Leninist principles of the Communist Party spirit, class and tendentiousness.

Artistic method of socialist realism asserted the necessity of historicism in art: "historyspecific artistic reality needs to portray 'threedimensionality', as the writer seeks to capture, in the words of M. Gorky, the 'three realities': the past, the present and the future" (Borev, 2001: 405). The most striking manifestation of this thesis was the tetralogy novel "Uigu chok Ulug-Khem" ("Ulug-Khem the Restless") by the National Writer of Tuvan ASSR, Kyzyl-Enik Kudazhy. The same trend exists in the novels, plays and poetic works by Tuvan classics: Salchak Toka (autobiographical trilogy "Arattyn sozu" "The Word of Arat"), Stepan Saryg-ool ("Angyrooldun toozhuzu" - "The Story of a Bright Boy"), Sergei Piurbiu (play "Kyzyl uer" - "The Red Flood”), Mongush Kenin-Lopsan ("UlugHemnin shapkyny" - "Rapids of the Great River", "Hereezhennin chorgaaraly" - "The Fate of a Woman"), Yurii Kiunzhgesh (poem "Ynakshyl bolgash kilen dugaiynda" - "Song of Love and Anger", "Kok-El"), etc.

It should be noted that in the beginning of this period, in the 60-70-s, almost all Tuvan literature was characterized by direct political bias, glorifying the Communist party and all the ideas and ways of development of the socialist society. But the artistic method of socialist realism forced the writers to create large-scale, colourful works in the realistic tradition to depict the image of the socialist society. It is manifested in the works by the leading Tuvan writers. The class approach and civil-patriotic pathos, that began in the 30-40-s, was still present. 
In this period of development one of the main tasks of socialist realistic art is to include a person into public life; this is the distinctive feature of the genre. However, the Soviet era art asserted that "happiness of a man is in the dedication and service to the 'happy future of the humankind', and the source of historical optimism and fullness of life and social sense is in the involvement of the man in the creation of something new" (Borev, 2001: 396). Such pathos was imbued with the works of Soviet literature.

In these years there was an increase in the ideological and artistic level of Tuvan literature. The greatest development occurred in the epic and lyric genres.

The theme of the Revolution and the image of Lenin were present in the works of all the writers of the 60-70-s: "Partiia dugaiynda sos" ("Word of the Party") by S. Piurbiu, "Adyzhok" by S. Siuriun-ool, "Lenin bolgash Ava" ("Lenin and Mother") by V. Sagaan-ool, "Partiia-bile kady" ("Together with the Party"), "Covet churttun eeleri bis" ("We are the Owners of the Soviet Country") by O. Suvakpit, etc. In civic lyrics, the theme of friendship of the nations dominated, for example, in the poem "Oorushkumnu ulezhir deesh" ("To Share the Joy") by Iu. Kiunzhgesh, "Monge aldar" ("Eternal Glory") by O. Saganool, "What is Tuva?", "If You are a Man" by A. Emelianov, "Syldystarzhe oruk" ("The Way to the Stars") by S. Piurbiu, "Covet huulgaazyn" ("The Soviet Magic") by B. Hovenmei, etc. The military and patriotic theme, the theme of labour became the leitmotif of many works. The international theme is found in such poems as "Meen aalchylarym" ("My Guests"), "Churek yshkash Africa" ("Heart-shaped Africa") by Iu. Kiunzhgesh, "Karaam odu" ("The Light of My Eyes") by I. Irgit.

Love poetry reached a very high level, as many poems became popular songs: "Kara-kara karaktar" ("Black-Black Eyes”), "Syldys" (“The
Star") by S. Siuriun-ool, "Kusku seserlikte" ("In the Autumn Garden") by S. Piurbiu, "Choiganmaa", "Hereezhenge ynak chordum" ("I Love a Woman") by M. Dorzhu, "Hulumzuruun korup chor men" ("Your Smile in Front of Me") by O. Suvakpit, "Didim salgyn" ("Brave Light Wind") by K. Kudazhy, "Shonchalai" by Z. Namzyrai and others. The image of the mother penetrates into the depths of the reader's soul in poetry by B. Seren-ool, M. Dorzhu, S. Kozlova, A. Darzhai, M. Olchei-ool, A. Uerzhaa, N. Kuular et al.

The connection between the inner world of man with nature as an innovation in Tuvan poetry of the 1970-80-s deserves a special mentioning. It is clearly expressed in the poem "Kok-kok daglarym" ("The Blue Mountain") by S. Siuriunool, "Chagytai", "Aldyn kus" ("Golden Autumn") by S. Saryg-ool, "Yraazhy Hem" ("The Singing River") by M. Kenin-Lopsan, "Daglarym" ("My Mountains") by A. Darzhai, etc. There are philosophical lyric sprouts, such as "Churttalganyn aialgazy" ("Music of Life") by S. Piurbiu, "Ie holu" ("Mother's Hands") by B. Hovenmei, "Churttalganyn unezi" ("The Value of Life"), "Saian" by O. Suvakpit, "Nogaan at" ("The Green Horse") by A. Uerzhaa, etc.

As years passed by, the genre system established in Tuvan poetry got improved, supplemented with such lyrical genres and universal poetry forms as sonnet, elegy, ode, hymn, dedication (Iu. Kiunzhgesh, M. KeninLopsan, A. Darzhai, V. Seren-ool, K. Cherligool et al.), gazelle, Rubaiyat (I. Irgit, A. Uerzhaa, B. Taraachy).

1980 was remarkable for the ideological and aesthetic innovations, raise of pathos and an active search for new artistic forms and genres in Tuvan poetry. Lyrical miniatures of a certain number of lines, referred to as "ushteen oduruglar" (three lines), "dortteen oduruglar" (four lines), "beshteen oduruglar" (five rows), 
etc. are one of the distinctive tendencies of the decade. Almost all of the poetry collections contained some lyrical miniatures. Among them there are, for example, collections of poetry by Iu. Kiunzhgesh, K. Kudazhy, A. Darzhai, B. Seren-ool, A. Uerzhaa, N. Kuular and others. Typically, these poets turned to the miniature genre of Ozhuk Dazhy (tercet), originated in the late 80-s (Mizhit, 2013). Great interest is drawn by the poetic experiments of those years, the use of such new forms and structures as "arbannar" ("Decima") by A. Darzhai, "heeler" ("patterns") by A. Uerzhaa, "iligler", "soomner", "karyshtar" (traditional measures of length) by V. Seren-ool.

A major role in the development of Tuvan literature was played by lyric-epic genres, i.e. ballads, poems, and fables. For example, those are historical ballads of ancient warriors, heroes, such as "Kok-El" and "Bagyrnyn hylyzhy" ("Bagyr's Sword") by Iu. Kiunzhgesh, "Shapkynchy" ("The Messenger") by S. Piurbiu, "Herelmaa" by E. Tanova, etc. Socio-historical problems are widely disclosed in the following poems: "Uem bolgash ue-chergem dugaiynda" ("About the Time and Contemporaries") by S. Piurbiu, telling the story of the revolutionary way of Tuvan people, of the main stages in Tuva history: old Tuva, the Revolution, building a new life, anti-feudal struggle, the Great Patriotic war participated by Tuvan volunteers, joining the People's Republic of Tuva to the Russian Federation, the socialist transformation, etc. All these events are revealed in a close relation to the fate, good and bad luck of the protagonists. For this poem, the people's writer of Tuvan ASSR S. Piurbiu was awarded with the State Prize of Tuvan ASSR. For the poem "Ulug-Hemim" ("My Yenisei"), which draws a parallel between the socio-historical painting and nature, the people's writer of Tuvan ASSR S. Saryg-ool was also awarded with the State Prize of Tuvan ASSR. The poems "Ottuk" and "Bichii bashky" ("The
Little Teacher") by M. Kenin-Lopsan were also acknowledged by the readers. In his work "The Little Teacher", the author tells the story of the early Cultural Revolution in Tuva. Distinguished artistic and aesthetic features are typical for ballads by S. Siuriun-ool, O. Suvakpit, S. Tamba, K. Kudazhy and fables by B. Hovenmei, Iu. Kiunzhgesh, S. Siuriun-ool and others.

The 1960-80-s were the years of active development in children's literature, with the brightest works being; the fairy tale "Mergen bichiiler bolgash melegei kuchutenner" ("Wise Children and Stupid Giants") by S. Piurbiu, the poem "Salgakchylar" ("New Generation") by L. Chadamba, "Chechekterim" ("My Flowers"), "Deerde kapusta" ("Cabbage in the Sky") by E. Kechil-ool, "Bistin onnukterivis" ("Our Friends") by S. Saryg-ool, "Oktiabrdan oktargaizhe" ("From October to the Cosmos") by B. Hovenmei, "Hunneerek" ("The Small Sun") by K.-K. Choodu, the play "Ilbilig sogun" ("Magic Arrow") by E. Tanova and others. Tuvan children's prose was developing mostly in the folklore and ethnographic context (Chamzyryn, 2009). The distinctive folklore ideological and aesthetic qualities are found in different stories and novels for children by the following authors: D. Sagan-ool ("Kezhiktig syldys"-“Lucky Star"), S. Siuriun-ool("Chaigy hunner" - "Summer days"), E. Tanova ("Akym dugaiynda toozhu" - "The Tale of the Elder Brother"), M. Ergep ("Odugende Chaylag" "Magic Odugen"), L. Chadamba ("Taiganyn oglu" - "Son of Taiga", "Aian-choruk" "The Journey"), M. Kenin-Lopsan ("Deernin korunchuu" - "Sky Mirror"), K. Cherligool ("Kuduruk" - "The Tail"), A. Shoiun ("Balyktar ashtai beer" - "Hungry Fish"), Ch. Chuldum ("Kyrgan-avavys aptarazy" "Granny's Chest"), K. Chamyian ("Mongun Ottuk" - "Silver steel"), M. Duiungar ("Iii aaldyn oglu" - "The Son of Two Families"). 
The story "Shonchalay" by K. Kudazhy is considered to be a model of lyrical prose.

A great achievement of the Soviet era Tuvan literature was a significant development of epic literature. According to the well-known critic A.K. Kalzan, the leading genre of Tuvan literature in the 1970-80-s was prose (Kalzan, 1991). During these years, the classic works of Tuvan literature were created.

As it has been noted before, in the year 1960 Tuvan prose was mostly historic, joining two times: the past and the present of Tuvan socialist system. It includes the above mentioned major works of Tuvan literature, as well as the unfinished novel "Aldan durgun" ("Sixty Fugitives") by S. Sarygool, "Homdu daiyny" ("Battle in Koptu") by S. Toka, etc. We should also notice that being the most famous Tuvan novel in the literature space, meeting the requirements of its time, was the novel "The Word of Arat" by the National Writer of Tuvan ASSR Salchak Toka, who, by means of artistic expression, for the first time announced the existence of the Tuvan people, its history and its socialistic development. For this achievement, S.K. Toka was awarded with the Stalin Prize, and the book was translated into over 20 languages of the USSR and the world (mainly, Volume I of the book). The third volume of the novel by S. Toka was released in 1964, and the full version of the novel in 3 volumes was translated into Russian by Temir A. (A.A. Palmbah) and published in 1972.

Since the mid 70-s, the modern theme of literature was established. Despite its aesthetic roots going back to the folk myths, legends and folklore stories, Tuvan prose began to display modern reality. The interest for the contemporary image of the Soviet man began to grow; his working biography, heroic deeds, moral qualities and social significance got in the centre of attention. At the same time, the traditional national character could still be seen through the new features of the socialist way of life.
This category includes novels and stories by the following writers: the National Writer of Tuvan ASSR M. Kenin-Lopsan ("Tenin samy" - "Dance of Capricorn", "Chylgychynyn oo" - "Yurt of a Herdsman"), O. Sagan-ool ("Dospester" - "The Obsessed", "Toreen kizhiler" - "Native people"), the National Writer of Tuvan ASSR S. Siuriun-ool ("Avazynga dangyrak" - "Oath to His Mother", "Kymnyn oglul?" - "Whose Son is That?", "Oskea kadai" - "Strange woman"), the National Writer of Tuvan ASSR K. Kudazhy ("YrlygBulak", "Yrzhym Bulun" - "Quiet Corner", "Yrak bulut" - "High Cloud"), the National Writer of Tuva E. Tanova ("Kara-Bay"), the National Writer of Tuva A. Darzhai ("Syldystygda dush" - "Sleep Under the Stars", "Churttaaryn kuzezinze" - "If You Want to Live"), K. Cherligool ("Shoraan"), A. Emelianov ("From the World Does Not Go"), N. Serdobov ("Scorched War"), M. Kozheldei ("Shyn kaidal?" - "Where is the Truth?”), E. Dongak ("Ergi honashtar" - "Old Camp", "Syyn chady" - "Maral Spell”), Sh. Kuular ("Baglaash" - "Hitching Post"), short stories and novels by M. Dorzhu, Ch. Irbizhei, Sh. Suvan.

Tuva rural life (rustic realism) is described in the novels by S. Siuriun-ool "Ynakshyl-dyr" ("This is Love"), telling the story of love of a Russian girl for a Tuvan lad, "Ozalaash Khem" ("Blind River"), "Leitenantynyn daalgazy" ("Lieutenant's Assignment"), narrating of the friendship between Russians and Tuvans. In the stories by O. Sagan-ool ("Dospester" "Fidget", "Toreen kizhiler" - "Native people"), D. Begzi ("Onnukter dugaiynda toozhu" - "A Tale of Friends") the socialist transformation in Tuva is described, presenting the efforts of a Soviet person, their personal life, relationship with their loved ones, etc. In the story "Yrzhym Bulun" ("Quiet Corner") by K. Kudazhy the main idea is that happiness of man depends on his social life. 
Literature explores significant social and psychological issues, revealing the problems of modern society (alcoholism, drug addiction, crime, moral degradation, etc.); for example, the stories and novels of the National Writer of Tuvan ASSR Salim Siuriun-ool tells everything about the whole Republic of Tuva, both the older and the younger generation. His readers learn the social and moral issues of his time, his contemporaries, their spiritual experience and aspirations, their conflicts. Acute social orientation, identification of moral diseases that threaten the foundations of society, sparkling humour and compassion for his characters are the distinctive features of his works, that have gained him great popularity among the readers.

"Small prose" was revived in the 80-s by such writers as F. Seglenmei ("Chechen chugaalar" - "Short Stories"), V. Sagaanool ("Kyzyl duzalamchy" - "Red Aid"), A. Darzhai ("Tarzan”, “Congar-Irei”), E. Dongak ("Talygyrda Changy" - "Echo in the Distance", "Choldak-Anchynyn chugaalary" - "Stories of Choldak-Anchy"), M. Kenin-Lopsan ("Haiyralyg Kalchan-Shilgi" - "White-Fronted Red Horse"), K. Cherlig-ool ("Daglarym aialgazy" - "Melody of the Mountain"), M. Dorzhu ("Syrgalar" - "The Earrings"), Ch. Irbizhei ("Ynak ezhin kymyl?" “Who's Your Favourite One?”), etc. These pieces are full of aesthetic ideas, strong images, deep psychology.

Of particular interest are the satirical, realistic stories by V. Mongush, represented by: "Katky bazhy katkan eves..." ("Fun but Sad"), "Kadai-kystyn chany charash" ("Beautiful Woman with Character"), "Kattyramzaan chany charash" ("Grinning Her Character is Beautiful"), "Bodun maktaar bolbas tenek" ("Fools, Praising Themselves"), loved by both adults and children.

Essays and journalism of the 1960-80$\mathrm{s}$ are represented by such authors as S. Toka, K. Kudazhy, M. Pakhomov, L. Chadamba,
O. Suvakpit, S. Kozlova, M. Khadakhane, and others. Thus, in this period Tuvan writers mastered many prose genres (novel, story, story, novel, essay).

Dramaturgy of the Soviet period is of different historical and social orientation. Highlights of Tuvan dramaturgy are the historical plays, "Sambazhyk" by V. Kok-ool, "Kyzyl uer" ("Red Flood") by S. Piurbiu, telling the story of the national liberation movement in Tuva; "Naiyral" ("Friendship") created in collaboration by V. Kok-ool and S. Piurbiu narrates of friendship between Tuvan and Russian peasants; "Hannyg ister" ("Bloody Footprints") by $\mathrm{Ch}$. Ondar, a play of historical preservation of the people during the conquest of Genghis Khan; "Ynakshyldy kamnaar herek" ("Love Should Be Protected") by S. Piurbiu, "On bir" ("Eleven"), "Belek-kys emchi” ("Doctor Belekkys") by K. Kudazhy, "Sooskenner chechektelip turda" ("When Acacia Blossoms") by V. Serenool, comedies "Dolumanyn huulgaazyny" ("Transformation of Doluma"), "Incheek" by K. Kudazhy and "Songulda" ("Elections") by Ch. Ondar. According to the authors of "Essays of Tuvan literature", "literature adequately fulfils its educational role in the formation of spiritual culture in the new era in the history of the people" (Kalzan, 1975: 205). In art, the realism of these years bulges socialist humanism.

Based on national traditions, enriched by the experience of development of literature, especially Russian, Tuvan writers attempt to engage the readers in the ideas of socialist patriotism and internationalism. This approach began to weaken after the mid 80 -s.

In the late 80-s both in Tuvan and Russian literature the artistic methods of Soviet art began to be denied. It started with the following idea: "Man is not the fuel that gives energy to an abstract process. The future is built by people and for people. Man must give himself to the people: 
selfish isolation deprives life of its meaning, turns it into an absurd (the nomination and approval of the idea - are the merits of art in socialist realism). If spiritual growth of the society is fraught with degradation of the individual, the society and development, if it contradicts the interests of the individual, it is detrimental for him and the society as a whole. After 1984, these ideas underlaid perestroika and glasnost, and after 1991 it became the foundation for democratization of the society" (Borev, 2001: 412). Ideological meaning of this thesis, in particular, was expressed by the National Writer of Tuvan ASSR Salim Siuriunool in his work "Tyvalaar kuskun" - "TuvanSpeaking Raven".

Despite the ongoing bureaucratic intervention of the party into literature, the artistic traditions of the past contributed to the emergence of a number of valuable works. However, it should be stated that during the construction of socialism under the influence of ideological principles Tuvan writers avoided mentioning spiritual culture, religious and mythological world, proclaiming atheism. Only after the 90 -s picture began to change.

The most striking manifestation of rejecting the principles of socialist realism and the social and politicized view of reality is in the work of young poets of the time who declared themselves in 1980: Igor Irgit, Anton Uerzhaa and Nikolai Kuular. A detailed literary analysis of poetry was made by the leading literary critic A.K. Kalzan (Kalzan, 1991). The author notes that these poets refused Tuvan journalistic poetry, writing true lyrics, expressing the inner world of the soul (Kalzan, 1991: 113). (This approach, in our view, was created by poets Mongush Dorzhu and Alexandr Darzhai.) These poets have left an indelible mark in the history of Tuvan literature with their poems: "Tyva dylym" - "My Tuvan Language", "Tyva oomge" - "My Tuvan Yurt", "Karaam odu" - "Light of My Eyes", "Chalyy uem, dalashpa daan" - "Not So Fast, My Youth" (I. Irgit), "Ush chus harlyg kyrgan kuskunnun chagyy" - "Tame 300-Year-Old Raven", "Monge baglaash" - "Eternal Hitching Post", "Yrzhym dune yglaan sen be?" - "Have You Cried On a Quiet Night?", "Alazhymga kalgyp keldim" - “I Have Acquired to The River Alash" (A. Uerzhaa), "Chaygy chas" - "Summer Rain", "Chettirdim, meen toreen churtum" - "Thank You, My Motherland", "Kyzhyn" - "In Winter", "At dugaiynda ballada" - "The Ballad of The Horse" (N. Kuular). They express a new outlook on life, the idea of the continuity of traditional culture and the generations, updated plot, architectonic and artistic techniques.

The mid 80 -s - early 90 -s is the end of socialist realism and the beginning of pluralistic development of national art. During these years, the literature of socialist realism began to assert relationship with the national tradition. Tuvan writers, like all writers of the Soviet Union, came to the conclusion that the people in the revolutionary impulse of split with their national tradition, lose ground for socially relevant human life. Without connection with their ethnic culture, their identity is empty, confused and violent. The result was a new look on poetry, manifested in the pieces by A. Darzhai ("Tyva ogler" - "Tuvan Yurts", "Tuva dylym" - "My Tuvan Language"), A. Uerzhaa ("Monge baglaash" - "Eternal Hitching Post"), N. Kuular ("Dal dushte bodanyyshkyn" "Meditation at Noon"), E. Mizhit ("Kezernin baldyzy" - "Geser's Mace"), etc. The idea of an indissoluble connection of human life with the life of the people is heard in the rhythmic formula of A. Darzhai: "Damdyn-dyr men. Dalaiynga duzam bar iin” ("I am your tiny drop. I cannot live without the sea").

In the years of perestroika in Russia, socialist realism art for the first time began to realize the two-way process: history is not only a common history of the humankind, it is also history of an 
individual. Through slogans of "happy future", the idea of human self-worth in Tuvan literature begins to manifest itself, for example, in the novel "Churttaaryn kuzezinze" ("If You Want to Live") by A. Darzhai, the poem "Nogaan at" ("Green Horse") by A. Uerzhaa and other works of the time.

The analysed period in the history of Tuvan literature is characterized by translation of Soviet and foreign literature into Tuvan language, as well as translation of works by Tuvan authors into Russian. Among the outstanding translators, there are S. Piurbiu, A. Delger-ool, Yu. Kiunzegesh, M. Dorzhu, S. Kozlova, M. Khadakhane, G. Printseva, A. Darzhai, B. Seren-ool and others. In those years, friendships between Tuvan writers with representatives of other national literatures grew stronger through the purposefully conducted seminars and conferences, Days and Decades of literature in all the republics of the Soviet Union.

Tuvan literature of the Soviet period is considered to be one of the most productive and intensive periods in the literary life of Tuva.

Democratization of society in the early 1990 -s and the collapse of the party influence over art contributed to the fact that the Tuvan writers sought to understand the history in all its drama, revealing the true social and moral problems of society. The post-Soviet time was a specific literary and cultural situation in Tuva, as well as in all over Russia.

\section{References}

Borev, Iu.B. (2001). Epokha realizma: chelovek stradaet, neset poteri, no vystoit. Teoreticheskaia istoriia iskusstva [The Realism Age: The Man Suffers Pain and Loss, But Keeps Standing. The Theoretical History of Art]. In: Teoriia literatury. Tom IV. Literaturnyy protsess [Literature and Literary Theory. Volume IV. The Literary Process], 405.

Chamzyryn, E.T. (2009). Etnopoeticheskie osobennosti tuvinskoy detskoy prozy [Ethnopoetic Features of Tuvan Children's Prose]. Kyzyl, Tuvan University PRess, 143 p.

Gamzatov, G.G. (2003). Dvadtsatyy vek kak epokha national'nykh literatur i regional nykh literaturnykh obshchnostei [The Twentieth Century as The Era of Ethnic Literatures and Regional Literary Communities], In: XX stoletie i istoricheskie sud by national nykh khudozhestvennykh kul tur: Materialy Vserossiiskoi nauchnoi konferentsii [The Twentieth Century and the Historical Fate of the Ethnic Artistic Cultures. Proceedings of All-Russian Scientific Conference]. Makhachkala, 11-22.

Istoriia tuvinskoy literatury. T. I. Istoki. Literatura Tuvinskoi Narodnoy Respubliki (1921-1944) [The History of Tuvan Literature. Vol. I. Origins. Literature of The Tuvan People's Republic (1921-1944)] (2013). Executive editor Bicheldei, K.A.; editorial board: Mizhit, L.S. (project Director) etc.; Tuvan Institute of humanitarian research. Novosibirsk, Siberian Branch of the Russian Academy of Sciences, $266 \mathrm{p}$.

Iusufov, R.F. (1996). Istoriosofiia i literaturnyy protsess: srednie veka i novoe vremia [Historical Philosophy and Literary Process: Middle Ages and Modern Times]. Moscow, World Literature Institute of the Russian Academy of Sciences, 300 p.

Kalzan, A.K. (1991). Ozuldening demdekteri: chogaal-saigarylgalyg chuulder [Signs of Growth: Literary Critical Articles]. Kyzyl, Tuvan Book Printing House, 300 p.

Kalzan, A.K., Kuular, D.S., Kenin-Lopsan, M.B., Kiunzegesh, Iu.Sh. (1964). Tyva literatura. Dopchu tooguzu [Tuvan Literature. A Brief Essay]. Kyzyl, Tuvan Book Printing House, 100 p.

Kalzan, A.K., Kuular, D.S., Khadakhane, M.A. (1975). Tyva literaturanyn tooguzunun ocherkteri [Essays on the History of Tuvan Literature]. Kyzyl, Tuvan Book Printing House, 200 p.

$$
-577-
$$


Kuular, D.S. (1970). Tuvinskaia poeziia. Ocherk istorii [Tuvan Poetry. The Essay of History]. Kyzyl, Tuvan Book Printing House, 139 p.

Mizhit, L.S. (2013). Tuvinskoe trekhstishie. Triada v tuvinskoy traditsionnoy kul ture [Tuvan Tercet. Triad in Tuvan Traditional Culture]. Novosibirsk, Printing House of the Siberian Branch of the Russian Academy of Sciences, $138 \mathrm{p}$.

Samdan, Z.B. (1987). Ot fol klora k literature (na materiale tuvinskoy prozy 40-70-h godov) [From Folklore to Literature (Based on Tuvan prose of the 1940-70-s)]. Kyzyl, Tuvan Book Printing House, $80 \mathrm{p}$.

\section{Развитие тувинской литературы в Советский период (1960-80-е гг.)}

Л.С. Мижит

Тувинский институт гуманитарных и прикладных сочиально-экономических исследований Республика Тува, 667000, Кызыл, ул. Кочетова, 4

В статье исследуется история тувинской литературы в Советскую эпоху, а именно в 196080-е гz., когда она получила интенсивное развитие в рамках творческого диалога литератур и культур разных народов Советского Союза. Это самый плодотворный и насыщеенный период становления художественной литературы тувинцев не только в плане обогащения жанровой системы, но и в плане создания крупных, этапных произведений национальной литературы: романов, пьес и поэзии основоположников тувинской литературы - Салчака Токи, Степана Сарыг-оола, Сергея Пюрбю, Виктора Кок-оола, а также писателей следующего поколения - Кызыл-Эника Кудажы, Монгуша Кенин-Лопсана, Салима Сюрюн-оола, Василия Монгуша, Юрия Кюнзегеша и других. Несмотря на литературное творчество под влиянием коммунистической идеологии, подчиненной принципам сочреализма, некоторые тувинские поэты (Монгуш Доржу, Александр Даржай, Игорь Иргит, Антон Уержаа, Николай Куулар) смогли отказаться от соииально-политизированного взгляда на действительность и выйти из стереотипа.

Статья обобщает одну из ярких ступеней развития тувинской литературы и имеет практическое значение при исследовании произведений Советского периода по современным научным парадигмам.

Ключевые слова: тувинская литература, история литературы, Советский период, сочреализм, идеологизированность, пафос, проза, поэзия, драматургия, детская литература, новаторство, литературный проиесс.

Научная специиальность: 10.01.02 - литература народов Российской Федерации (тувинская литература). 